\title{
Sibling stem cell donors' perceptions of experiences of donation
}

\author{
Annika M. Kisch*1, Anna Forsberg 2,3 \\ ${ }^{1}$ Department of Haematology, Skåne University Hospital, Lund, Sweden \\ ${ }^{2}$ Department of Health Sciences, Lund University, Lund, Sweden \\ ${ }^{3}$ Department of Thoracic Surgery, Skåne University Hospital, Lund, Sweden
}

Received: June 26, 2017

Accepted: July 30, 2017

Online Published: August 7, 2017

DOI: $10.5430 /$ cns.v5n $4 \mathrm{p} 23$

URL: https://doi.org/10.5430/cns.v5n4p23

\begin{abstract}
Objective: What and when should we tell sibling donors about the donation process? Although we provide extensive information to sibling stem cell donors, we lack knowledge of their perceptions and how they change during the donation process. Therefore, the aim of this study was to explore sibling donors' perceptions of experiences of stem cell donation from pre-donation to one year afterwards.

Methods: Applying a phenomenographic approach we performed an in-depth, longitudinal exploration of adult sibling donors' perceptions of experiences based on 29 open-ended interviews performed before donation, as well as three and twelve months afterwards. Ten consecutive adult sibling donors with a median age of 54 years (range 26-66 years) due to donate stem cells at one Swedish transplant centre participated.

Results: A detailed learning process among sibling stem cell donors during the first year after donation was identified through 83 different perceptions pertaining to motive, obligation, responsibility, preparation, circumstances, recovery and relationship. The perceptions changed over the first year after donation due to experiences of duty, pressure, burden, security, learning, struggle and closeness. Educational strategies and tools must cover all these perceptions to narrow the sibling donors' knowledge gap and support their learning process.

Conclusions: In the course of the year sibling stem cell donors' perceptions of their experiences change and thereby their need for education, information and support. As the learning process stems from a range of experiences, there is a need to individualise the care and further study sibling stem cell donors' levels of burden and distress.
\end{abstract}

Key Words: Stem cell donation, Sibling, Qualitative study, Interviews, Learning process, Phenomenography

\section{INTRODUCTION}

This is the first longitudinal phenomenographic study to explore stem cell donors' learning process from pre-donation to the end of the first year after donating haematopoietic stem cells to a sibling with a serious illness, usually a haematological malignancy. The rationale behind this study is that we provide extensive information to sibling stem cell donors without knowledge of their learning process, i.e., how they perceive and understand the phenomenon of sibling stem cell donation. However, as healthcare professionals we tend to provide information about what we consider important. If we are unaware of the sibling donor's complete situation there is a risk of our message being inaccurate or misunderstood.

Stem cell donation is a fairly common procedure today, with

*Correspondence: Annika M. Kisch; Email: annika.m.kisch@skane.se; Address: Department of Haematology, Skåne University hospital, S-221 85 Lund, Sweden.

Published by Sciedu Press 
more than 15,000 stem cell transplantations performed in Europe every year ${ }^{[1]}$ and over 30,000 worldwide. ${ }^{[2]}$ In Sweden, the number is around 280 per year, with a one year recipient survival rate of $70 \%-80 \% .^{[3]}$ In around one third of all stem cell transplantations the stem cells are from sibling donors. These donors face a procedure where haematopoietic stem cells are either collected through harvesting bone marrow (BM) or, more commonly, by peripheral blood stem cell (PBSC) collection. The sibling donor is informed about the common side effects, i.e., fatigue, headache, bone pain, muscle pain and nausea, which are usually transient. Major complications are rare, but events such as deep vein thrombosis, splenic rupture and cardiac arrest have been reported. ${ }^{[4,5]}$ What we do know from previous research is that sibling stem cell donors are in a vulnerable situation and go through a complex process in which they became involved by chance. They were asked to become a donor; it was not a voluntary decision. They have to deal with a mixture of experiences, such as anxiety and guilt as well as happiness and pride, which they most often do not discuss with anyone. ${ }^{[6-9]}$ Sibling donors are frequently concerned about the outcome of the transplantation and feel that they have a responsibility to do what needs to be done to help a family member. ${ }^{[6-9]}$ Information and cooperation are of vital importance to prevent unnecessary harm to the healthy sibling performing the donation. Understanding the whole situation of the sibling donor, including perceptions and experiences, is essential for providing person-centred information and care. ${ }^{[10]}$ Therefore, the aim was to explore sibling donors' perceptions of experiences of stem cell donation from pre-donation to one year afterwards. The research question was; how do sibling donors perceive the phenomenon of stem cell donation based on their experience of donating stem cells to a sibling with a serious illness?

\section{MethodS}

The methodological point of departure was phenomenography in nursing research, and the protocol described below by Sjöstrom \& Dahlgren. ${ }^{[11]}$ Phenomenography is the empirical model for exploring the different ways in which people perceive, experience, assimilate, understand and form a conception of different phenomena and aspects of the surrounding world. ${ }^{[12]}$ The methodological purpose is to explain variations in perceptions of a phenomenon such as sibling stem cell donation. Sibling stem cell donors can only communicate the world that they experience. Persons perceive the world differently and these differences can be described and communicated to reach an understanding among others. The most important finding of phenomenographic investigations is description of these differences and similarities. ${ }^{[13]}$ Percep- tions of experiences play a central role in phenomenography. Subsequently a routine procedure is to interview the participants about the way in which they perceive a specific phenomenon. Initially, the two authors read all transcripts separately in line with step 1-3. Both the authors participated also in the subsequent steps:

(1) Familiarisation: to obtain an overview the interviews were read through

(2) Compilation: we identified the most important parts of the informants' responses

(3) Condensation: in order to identify the central parts of longer responses or dialogues some responses were shortened

(4) Grouping: included that similar responses were tentatively grouped or classified

(5) Comparison: in order to find associations between categories, preliminary comparison of the categories was made followed by a revision of the preliminary groups

(6) Naming: the categories were named for the purpose of highlighting their essence

(7) Contrastive comparison: the unique character or essence of each category and the linkage between them were described

Central conceptions in phenomenography are "what" and "how". The first order perspective is formed by "what" the informants' talk about and thereafter presented as domains (steps 1-2), The second order perspective presents "how" the participants talk about the "what". Steps 3-4 comprise the qualitatively different variations in perceptions. The categories are formed by descriptions at a more integrated level (steps 5-6). A description of the unique phenomenological character of each category constitutes the essence evidenced by step 7 .

\subsection{Context and setting}

The participants were recruited from one transplant centre at a university hospital in Sweden with a long history of performing stem cell transplantations. The physicians and nurses responsible for the donor were not the same as those responsible for the corresponding recipient. At this transplant centre sibling donors receive oral and written information about stem cell donation, including the benefits and risks for both the donor and the recipient. The information is provided 3-4 weeks pre-donation by a transplant physician and a transplant nurse. At the time this study took place follow-up consisted of blood samples and a telephone call at one month post-donation. 


\subsection{Participants and sampling}

Inclusion criteria were donors who were due to donate to a brother or sister, with both donor and recipient aged at least 18 years and able to speak and understand Swedish. From March 2011 to December 2012 ten consecutive sibling donors, five women and five men, due to donate stem cells to a seriously ill sibling at one Swedish transplant centre, were informed about and invited to participate in the study. The donors were approached by the first author (AK) at the time of their scheduled pre-donation information session and evaluation at the out-patient transplant clinic and informed about the study both orally and in writing. All ten donors agreed to participate. They ranged in age from 26-66 years (median 54 years). Demographics and sibling relationships are presented in Table 1. When written informed consent was obtained, the donors were scheduled for the pre-donation interview at a time and place chosen by themselves. No participants were excluded or declined participation after the initial contact.

\subsection{Ethical considerations in research}

The study was carried out in accordance with the existing requirements for research on human subjects as set out in the Declaration of Helsinki. ${ }^{[14]}$ The study was approved by the Regional Ethical Review Board for Southern Sweden (Dnr 2009/655). There were no financial incentives. All participants gave their written informed consent.

\subsection{Data collection}

A total of 29 open-ended interviews were scheduled and performed on three occasions; before the donation (median 4.5 days before donation), three months and twelve months afterwards. One participant declined to take part in the third interview because it made the donor feel uncomfortable and talking about the donation was experienced as a burden. The interviews lasted for an average of 60 minutes (range 20-198 minutes). In general the interviews performed pre-donation lasted longer than the interviews post-donation, especially those one year after donation. The majority of the interviews, which were audiotaped and transcribed verbatim, took place in a secluded room at the hospital and were performed by the first author (AK) who has long-standing experience of stem cell transplantation and donation, but was not involved in the participants' care. Open-ended questions were used and the interviews started with an open question: "Can you please tell me what it was like when you became aware that your sibling needed a stem cell donor for transplantation and you were asked if you were willing to be tested to become that donor?" and "Can you please tell me now, 3 months/one year after the donation, what being the stem cell donor to your sister/brother was like?" The interviews continued with additional questions in order to encourage the participants to expand on their answers and clarify their thoughts and experiences, including those expressed in previous interviews.

Table 1. Demographics and characteristics of the donors $(\mathrm{n}=10)$

\begin{tabular}{ll}
\hline Characteristics & \\
\hline Age, years & \\
- Median (range) & \\
Sex & 5 \\
- Female & 5 \\
- Male & \\
Occupation & 7 \\
- Employed & 3 \\
- Disability pension & \\
Marital status & 7 \\
- Married/living together & 3 \\
- Single & \\
Donation method & 9 \\
- PBSC & 1 \\
- BM & \\
Gender of recipient & 6 \\
- Female & 4 \\
- Male & \\
Relationship with recipient & \\
- Frequent contact & 6 \\
- Occasional/no contact & 4 \\
Recipient status 3 months post-donation & \\
- CR, doing well & 4 \\
- Severe acute GvHD & 5 \\
- Deceased & \\
Recipient status 1 year post-donation & \\
- CR, doing well & \\
- Severe chronic GvHD & \\
- Deceased & \\
\hline
\end{tabular}

Note $. \mathrm{BM}=$ Bone marrow; $\mathrm{CR}=$ complete remission; $\mathrm{GvHD}=$ graft versus host disease, $\mathrm{PBSC}=$ peripheral blood stem cells

\section{RESULTS}

The findings are described in seven categories based on 83 different perceptions identified in the interviews; Motive, Obligation, Responsibility, Preparation, Circumstances, Recovery and Relationship, as presented in Tables 2-5. The findings report the donors' actual statements, illustrating the variations in their perceptions.

\subsection{Category 1: Motive}

There were numerous different perceptions of experiences regarding the reason behind the donation, which are presented in detail in Table 2. These perceptions changed during the first year after donation. Pre-donation, the donors perceived that they themselves or the donation was the recipient's last chance. The donation was considered a contribution to science and an effort one makes as a human being in general and as a sibling in particular. It was also perceived as an obligation and an act of love. Three months after the donation there 
was less variation in the perceptions, which still focused on the opportunity to give life and help out. When one year had passed the perceptions of the reason for donation were even fewer and the need to discuss one's motives less pronounced. The strongest perception at this point in time was expressed by one donor who considered a refusal to donate as passive murder. All perceptions involved the motive for donation, which was driven by a sense of duty.

\subsection{Category 2: Obligation}

The participants mainly dealt with the question of voluntariness as a sibling pre-donation. Although the perceptions varied (see Table 2), they all agreed on the fact that donation was not optional. These perceptions of voluntariness were distinctly linked to the relationship that exists between siblings. Donation involved a degree of pressure, but after one year this had ceased to be an issue.

Table 2. The change in ten siblings' perceptions of the reasons behind and motives for donating stem cells based on 29 interviews

\begin{tabular}{|c|c|c|c|c|c|}
\hline \multirow{2}{*}{ Domain } & \multicolumn{3}{|c|}{ Variations of perceptions } & \multirow{2}{*}{ Category } & \multirow{2}{*}{ Essence } \\
\hline & Pre donation & Three months after the donation & One year after the donation & & \\
\hline $\begin{array}{l}\text { The reason } \\
\text { for donation }\end{array}$ & $\begin{array}{l}\text { - The donation is the recipient's last } \\
\text { chance. } \\
\text { - As a sibling you are the recipient's } \\
\text { last chance. } \\
\text { - The donation is an opportunity to } \\
\text { cure the recipient. } \\
\text { - Donating stem cells is about helping } \\
\text { another person. } \\
\text { - To donate is a contribution to science. } \\
\text { - You simply do this, even for a } \\
\text { stranger. } \\
\text { - Human values mean that you donate. } \\
\text { - The donation is an effort to help your } \\
\text { sibling. } \\
\text { - You have an obligation to donate to a } \\
\text { sibling. } \\
\text { - Donating is a matter of expressing } \\
\text { your love for your sibling. }\end{array}$ & $\begin{array}{l}\text { - Donating is an opportunity to } \\
\text { give life. } \\
\text { - To donate is an opportunity to } \\
\text { help. } \\
\text { - It is natural to donate to your } \\
\text { sibling. } \\
\text { - Donating is a matter of } \\
\text { common sense. } \\
\text { - Donating is about being there } \\
\text { for a sibling and getting help in } \\
\text { return when necessary. } \\
\text { - If you accept being evaluated } \\
\text { for donation you simply have } \\
\text { to proceed. }\end{array}$ & $\begin{array}{l}\text { - If you can prolong } \\
\text { someone's life that is } \\
\text { what you do. } \\
\text { - This is the sibling's last } \\
\text { chance. } \\
\text { - Not donating stem cells is } \\
\text { to murder someone } \\
\text { passively. }\end{array}$ & Motive & Duty \\
\hline Voluntariness & $\begin{array}{l}\text { - You have no option. } \\
\text { - When you are a sibling there is no } \\
\text { choice. } \\
\text { - Growing up together leads to a } \\
\text { certain kind of affection that you } \\
\text { can't ignore. } \\
\text { - You simply do anything for close } \\
\text { relatives. } \\
\text { - Being a donor means that you put } \\
\text { pressure on yourself. }\end{array}$ & $\begin{array}{l}\text { - You can't say no even if you } \\
\text { want to. }\end{array}$ & & Obligation & Pressure \\
\hline
\end{tabular}

Note. What the participants spoke about is presented in Domain, while the different perceptions of the donation experience are listed under Variations. The abstraction of the perceptions is presented under Category, while the inherent meaning, i.e., the experience that formed the perceptions can be found under Essence.

\subsection{Category 3: Responsibility}

As illustrated in Table 3, there were numerous different perceptions regarding one's own role as a donor throughout the year. Pre-donation, the perceptions involved both playing down the importance of one's effort and a belief that the process rested on the donor's shoulders. After three months, the focus changed to a strong sense of responsibility for the outcome of the transplantation. Another perception was that donors are entitled to receive some form of information about the recipient's wellbeing, which was maintained to some extent at the end of the post donation year. However, at this time point they also pondered a great deal about their responsibility if the outcome of the donation was poor or a failure. All these perceptions of one's own role and responsibility as a donor involved a sense of burden.

\subsection{Category 4: Preparation}

In Table 4, we present the perceptions of the preparation process, which were clearly evident during the pre-donation phase but not at all apparent after the donation had taken place. The various perceptions of preparation involved a sense of security. 
Table 3. The change in ten siblings' perceptions regarding their own role when donating stem cells based on 29 interviews

\begin{tabular}{|c|c|c|c|c|c|}
\hline \multirow{2}{*}{ Domain } & \multicolumn{3}{|c|}{ Variations of perceptions } & \multirow{2}{*}{ Category } & \multirow{2}{*}{ Essence } \\
\hline & Pre donation & Three months after the donation & One year after the donation & & \\
\hline $\begin{array}{l}\text { One's } \\
\text { own role }\end{array}$ & $\begin{array}{l}\text { - The donor's body has } \\
\text { to be healthy until the } \\
\text { donation is performed. } \\
\text { - The process rests on } \\
\text { my shoulders. } \\
\text { - I am responsible for the } \\
\text { recipient. If the } \\
\text { donation fails, I am a } \\
\text { failure. } \\
\text { - It is never the donor's } \\
\text { fault. } \\
\text { - Being a donor is not a } \\
\text { heroic act. }\end{array}$ & $\begin{array}{l}\text { - As a donor you are responsible for } \\
\text { how the stem cells work in the } \\
\text { sibling's body. } \\
\text { - You might feel that you have failed if } \\
\text { it does not work. } \\
\text { - Being a donor means feeling a great } \\
\text { responsibility for the recipient. } \\
\text { - As a donor, you are the recipient's } \\
\text { substitute who is ready to donate } \\
\text { again. } \\
\text { - If the recipient dies, it is not the } \\
\text { donor's fault. } \\
\text { - It is not a heroic act to be a donor. } \\
\text { - As a donor you have a special role in } \\
\text { the family or circle of acquaintances. } \\
\text { - The recipient is the centre of } \\
\text { attention. } \\
\text { - As a donor you are not entitled to } \\
\text { information from the health care } \\
\text { system regarding the recipient's } \\
\text { well-being. } \\
\text { - The donor has the right to general } \\
\text { information, but not about the } \\
\text { recipient's prognosis. } \\
\text { - As a donor you have the right to } \\
\text { know about the recipient's } \\
\text { well-being. }\end{array}$ & $\begin{array}{l}\text { - What you have done is something unique. } \\
\text { - When it does not work, it could cause } \\
\text { performance anxiety in the donor. } \\
\text { - The donor is never at fault if it does not } \\
\text { work. } \\
\text { - It is important to receive information about } \\
\text { the fact that you cannot be blamed, } \\
\text { otherwise you might feel guilty. } \\
\text { - It is not the donor's responsibility to ask for } \\
\text { a follow-up. } \\
\text { - If the recipient dies, the donor cannot be } \\
\text { blamed. } \\
\text { - The donor's stem cells are the reason for } \\
\text { the recipient's poor outcome. } \\
\text { - The donation is a small effort. } \\
\text { - The donor is no hero. } \\
\text { - The donor is untouchable. } \\
\text { - As a donor you are supposed to be the } \\
\text { strong one. } \\
\text { - As a donor, you have the right to know } \\
\text { about the recipient's well-being. } \\
\text { - As a donor you are not entitled to } \\
\text { information from the health care system } \\
\text { regarding the recipient's illness and } \\
\text { prognosis. } \\
\text { ine donor has the right to general } \\
\text { information. }\end{array}$ & Responsibility & Burden \\
\hline
\end{tabular}

Note. What the participants spoke about is presented in Domain, while the different perceptions of the donation experience are listed under Variations. The abstraction of the perceptions is presented under Category, while the inherent meaning, i.e., the experience that formed the perceptions can be found under Essence

Table 4. The change in ten siblings' perceptions regarding the pre-donation phase and the donation procedure and the outcome of donation based on 29 interviews

\begin{tabular}{|c|c|c|c|c|c|}
\hline \multirow{2}{*}{ Domain } & \multicolumn{3}{|c|}{ Variations of perceptions } & \multirow{2}{*}{ Category } & \multirow{2}{*}{ Essence } \\
\hline & Pre donation & Three months after the donation & One year after the donation & & \\
\hline $\begin{array}{l}\text { The pre-donation } \\
\text { phase }\end{array}$ & $\begin{array}{l}\text { - It is vital that the evaluation is } \\
\text { performed properly and that } \\
\text { the information is provided in } \\
\text { a manner that makes me feel } \\
\text { the donation is voluntary. } \\
\text { - It is good to have separate } \\
\text { procedures for the donor and } \\
\text { the recipient. } \\
\text { - The recipient's preparation is } \\
\text { demanding. }\end{array}$ & & & Preparation & Security \\
\hline $\begin{array}{l}\text { Procedure and } \\
\text { outcome }\end{array}$ & & $\begin{array}{l}\text { - This is a ground breaking } \\
\text { science. } \\
\text { - You can only donate a limited } \\
\text { amount of stem cells. } \\
\text { - There is no guarantee that the } \\
\text { recipient will be healthy and } \\
\text { survive. } \\
\text { - Obtaining the stem cells } \\
\text { involves manual work. } \\
\text { - As a donor, you benefit from the } \\
\text { donation because you get a } \\
\text { thorough check-up. Donation } \\
\text { serves as a guarantee of your } \\
\text { health status. }\end{array}$ & $\begin{array}{l}\text { - The donation and } \\
\text { transplantation of stem cells is } \\
\text { something complex. } \\
\text { - There is absolutely no guarantee } \\
\text { that the donation will work. } \\
\text { - It is up to you if you want facts } \\
\text { regarding the procedure. } \\
\text { - The stem cells are taken from } \\
\text { the back. } \\
\text { - There is a chemical reaction } \\
\text { between the donor's and the } \\
\text { recipient's stem cells. } \\
\text { - The chemotherapy is the worst } \\
\text { part for the recipient. }\end{array}$ & Circumstances & Learning \\
\hline
\end{tabular}

Note. What the participants spoke about is presented in Domain, while the different perceptions of the donation experience are listed under Variations. The abstraction of the perceptions is presented under Category, while the inherent meaning, i.e., the experience that formed the perceptions can be found under Essence 


\subsection{Category 5: Circumstances}

There were several perceptions of the procedure and outcome that did not occur until three months after the donation (see Table 4). These included what scientific progress has made possible and the potential limitation in the amount of stem cells that they could donate. However, they also perceived the donation as a health certificate, which was considered a benefit. After one year, the perceptions involved the recipient to a greater extent. Behind these perceptions was an implicit need to learn and comprehend what had happened as well as an understanding that the donation does not guarantee the recipient's survival and health.

\subsection{Category 6: Recovery}

Perceptions regarding their recovery first occurred after one year (see Table 5). Before that they dealt with aspects other than their own recuperation. Recovery was perceived as psychologically and emotionally demanding, with a need for individual follow-up regardless of the recipient's outcome. Recovery meant a struggle for the donors.

Table 5. The change in ten siblings' perceptions regarding the follow-up of the donation and the impact of the donation on the sibling relationship based on 29 interviews

\begin{tabular}{|c|c|c|c|c|c|}
\hline \multirow{2}{*}{ Domain } & \multicolumn{3}{|c|}{ Variations of perceptions } & \multirow{2}{*}{ Category } & \multirow{2}{*}{ Essence } \\
\hline & Pre donation & Three months after the donation & One year after the donation & & \\
\hline Follow-up & & & $\begin{array}{l}\text { - After one year, you are on your way to } \\
\text { being healthy again. } \\
\text { - The first six months are a struggle. } \\
\text { - Recovery time varies between individuals. } \\
\text { - There is a greater need for follow-up if the } \\
\text { recipient's outcome is poor. } \\
\text { - The donor needs follow-up regardless of } \\
\text { the recipient's outcome. } \\
\text { - The content of the follow-up should be } \\
\text { based on individual needs. }\end{array}$ & Recovery & Struggle \\
\hline $\begin{array}{l}\text { The impact of } \\
\text { the donation } \\
\text { on the sibling } \\
\text { relationship }\end{array}$ & & $\begin{array}{l}\text { - The donation makes the siblings } \\
\text { closer. } \\
\text { - The donation unites the family and } \\
\text { friends. } \\
\text { - The donation increases the } \\
\text { similarities between siblings. } \\
\text { - When you get older you have more in } \\
\text { common with your sibling. } \\
\text { - As a sibling donor you are both a } \\
\text { donor and a sibling at the same time. } \\
\text { - Donating to a stranger might be } \\
\text { easier. }\end{array}$ & $\begin{array}{l}\text { - The donation improved our relationship. } \\
\text { - It is the disease and not the donation that } \\
\text { brings the siblings together. } \\
\text { - The recipient is dependent on the donor, } \\
\text { on one single person. } \\
\text { - As a donor you are not supposed to receive } \\
\text { anything in return from your sibling. }\end{array}$ & Relationship & Closeness \\
\hline
\end{tabular}

Note. What the participants spoke about is presented in Domain, while the different perceptions of the donation experience are listed under Variations. The abstraction of the perceptions is presented under Category, while the inherent meaning, i.e., the experience that formed the perceptions can be found under Essence

\subsection{Category 7: Relationship}

Pre-donation, there were no perceptions regarding the impact of the donation on the sibling relationship, probably due to the vulnerable situation (see Table 5). After three months, they perceived that the donation had made the siblings closer and united the family. However, another perception was that donating to a stranger might be easier. After one year, the disease itself was considered more decisive for the sibling relationship than the actual donation and the recipient's dependence on the donor was acknowledged. Behind the various perceptions was a strong sense of closeness.

In summary, sibling donors perceive stem cell donation in various ways in terms of motive, obligation, responsibility, preparation, circumstances, recovery and relationship. The different perceptions stem from experiences of duty, pressure, burden, security, learning, struggle and closeness.

\section{Discussion}

\subsection{Methodological considerations and study limitations}

To our knowledge, this is the first longitudinal, phenomengraphic study performed in the context of stem cell donation and the clinical implications are promising in terms of developing various educational tools. The longitudinal design enabled us to detect changes in perceptions over time and thereby identify a possible learning process among the participants. Phenomenography was considered to be the obvious choice because it is the empirical study of the different ways in which people experience, perceive, apprehend, understand 
and conceptualize the various phenomena in and aspects of the world around them. A consecutive selection was employed as it constituted the most feasible way to collect data at the time of the study. The present study included ten participants, which is acceptable in phenomenographic research. The transferability to other stem cell donation settings is considered good, as the main focus of the study is highly relevant within the context of stem cell transplantation, despite being a rare phenomenon for the average nurse. In line with our wish to gather experiences from both male and female donors of various ages, the participants differed in terms of gender, age and relationship with the sick sibling, which made it possible to capture a variety of experiences. Although the median age of 54 years could be considered quite high, it is representative of donors nowadays. In the consecutive sampling procedure it was a coincidence that the number of male and female donors included in the study was the same. Nevertheless, further quantitative research is needed to enable generalization of these findings. While it is possible that participants with a predominantly positive attitude to stem cell donation were willing to participate, this was not reflected in the findings. According to Sjöström \& Dahlgren, ${ }^{[11]}$ the phenomenographic interview method is associated with at least two problems. The first concerns the participants' reason for participating in the study. In the present study, all participants stated that they had chosen to participate because they considered the question to be of major importance. During the recruitment period, all donors due to donate stem cells to a seriously ill sibling at one Swedish transplant unit were asked to and agreed to participate in the study. The second problem involves the researcher's understanding of what the participants are trying to communicate. She/he has to interpret the participants' statements during the interviews and formulate follow-up questions in order to obtain clarification and avoid misunderstandings. The interviewer is very familiar with the entire donation process, which was necessary in order to pose relevant follow-up questions, but was not personally involved in the care of the participants. The interviewer's pre-understanding from caring for sibling stem cell donors could have influenced the interpretation of the interviews. However, the open dialogue with the second author, who has no experience of stem cell donors but a vast knowledge of qualitative research, helped to reduce potential misinterpretation and increased the confirmability and trustworthiness of the study.

One limitation in the data collection procedure was the failure to sufficiently explain to the participants about whether the phenomenon under investigation was the actual donation or their relationship with the recipient. Analysis to define the first and second order perspective therefore resulted in a large amount of variations in the sibling donors' perceptions of experiences of both the procedure and their sibling relationship. We chose not to add quotations to the body of the text, thus the perceptions expressed by the donors during the interviews are instead presented in the tables (see Tables 2-5), thereby adequately illustrating the categories and increasing the credibility of the finding.

Another aspect that needs to be addressed is our decision to explore the essence of each category, which might be viewed as being too strongly inspired by the phenomenological tradition. Phenomenology searches for the essence or most invariant meaning of a phenomenon, while the aim of phenomenography is to discern and describe ways of experiencing phenomena in the surrounding world. We actually moved from maximum variation to invariance in the data analysis process, which is in line with steps 5-7 in the analysis method suggested by Sjöström and Dahlgren. Our interpretation is that comparing categories in order to try to determine borders between them and naming their essence could result in a description of the unique character of each category, which we have labelled the essence. We argue that our interpretation of steps 5-7 in the analysis has deepened the understanding about both the variations in and the presumed deeper experienced meaning behind the perceptions. Furthermore, the core objective of Sjöström and Dahlgren's method is the exploration of perceptions of experiences of something and not only perceptions. This implies that the respondents' perceptions are based on experiences of the phenomenon, in this case stem cell donation and the sibling relationship, and that the respondents presumably attribute some meaning to these experiences, which in turn shapes the perceptions. Others might argue that the method has been distorted and not fruitfully developed to fit an educational and nursing perspective. However, we disagree, as the chosen method was applied to fit nursing research by Sjöström and Dahlgren. In addition, the first and second order perspective was properly revealed. Disagreement might exist regarding whether or not the categories correctly reflect the variations in perceptions and whether or not steps 5-7 in the analysis should be interpreted to reflect a phenomenological direction.

Unfortunately, qualitative studies are not as common as and less established than quantitative studies in the field of transplantation. However, qualitative studies have addressed policy and clinically relevant topics, including living donors' motivations and perspectives. ${ }^{[7,15]}$ In contrast to quantitative studies, qualitative studies do not seek to quantify the frequency of opinions, but aim to obtain a broad range and depth of perspectives. The design of this study has been helpful for understanding the donors' learning process and 
will be used to develop educational resources and clinical practice guidelines after further testing of the findings.

As only Swedish-speaking donors were interviewed the study has an inherent socio-economic and cultural bias, which limits transferability. Nowadays it is not uncommon for sibling donors to travel to a foreign country, in this case Sweden, for health examination and donation. In order to gain knowledge about possible cultural differences, studies of sibling donors who speak other languages and live in countries other than that in which the donation is performed are required. The sample size might be considered small and thereby a weakness. However, the goal was an information-rich sample rather than a statistically representative one. ${ }^{[16]}$ The ten informants contributed rich information about their perceptions and experiences at each interview, which made the amount of data sufficient for in-depth analysis and transferability to other donors in the same situation. A strength of the study is that the same ten donors were longitudinally followed and interviewed three times in the course of one year, resulting in a total of 29 interviews and the possibility to deepen and further develop their responses.

\subsection{Discussion of the findings and clinical implications}

This study enabled us to identify a learning process for sibling stem cell donors that can form the basis for a tailored, timely and person-centred educational intervention. A detailed understanding of the sibling donor's learning process during the donation period provides a unique opportunity to develop various educational tools and strategies. We now know what topics to focus on, which perceptions should be addressed and the relevant time to discuss certain aspects of the donation.

As sibling donors perceive themselves as the recipient's last chance and as a possibility to provide a cure, they require information about the importance of their donation, but also that there is no guarantee it will cure the recipient. Because none of the donors considered the donation optional, it seems important to emphasise voluntariness, the possibility of not donating and to guarantee confidentiality pre-donation. However, because many donors experience a sense of responsibility for the recipient ${ }^{[6-9]}$ and a wish to donate, pre-donation information and education must include medical facts about donation and transplantation. They should also be informed about the benefits and risks for both donor and recipient, that donating stem cells means doing everything possible to save the sick sibling's life and that it is never the donor's fault if the transplantation is a failure.

As sibling donors' sense of responsibility for the recipient often seems to last throughout the first year after donation, there is a continuous need for tailored, person-centred information. As can be seen in Tables 4 and 5, the issues vary in relevance at different time points. The evaluation and preparation procedure is in focus pre-donation, while after donation the outcome, follow-up and the relationship with the recipient become more important.

This study reveals that sibling donors' recovery after stem cell donation takes time, especially the psychological and emotional aspects. In line with previous studies on kidney donors ${ }^{[17-19]}$ and stem cell donors, ${ }^{[6,7,9,20,21]}$ the participants in the present study reported that they felt rather isolated during the whole process and would have appreciated more support. Transplant centres must take responsibility for sibling donors during the whole donation process. Follow-up after donation is often sporadic and scarce, thus the donors' sense of being isolated and abandoned should be taken seriously. Almost 20 years ago, Switzer et al. ${ }^{[22]}$ suggested that sibling donors' psychosocial well-being should be monitored for extended periods post-donation and clinical interventions should be considered for both bereaved and non-bereaved sibling donors. Sadly and embarrassingly, this is still not done in most transplant centres.

Previous studies ${ }^{[6,7,9]}$ have revealed that the post-donation experience is often linked to the sibling recipient's outcome. In our study this is shown by donors reported thoughts and emotions about the recipient; i.e., happiness when the recipient recovered and felt better, or worries and a great sense of responsibility when the recipient became worse. The recipient's outcome should be taken into consideration in the follow-up of each individual donor by providing reasonable information about and explanation of the recipient's condition.

We are aware that the care of sibling donors differs between centres. The findings from this study constitute one step towards the development of guidelines for the care of sibling donors. Individually tailored education should be provided in different ways, both written and orally. Another method is to develop a digital application that addresses the perceptions identified in this study, which could be highly valuable for learning about the donor situation, especially for young donors who are usually familiar with various digital devices.

\subsection{Further research}

The findings reveal a great variety of perceptions that need to be tested further in a large sample to explore their relevance and generalisability. Further research is needed to verify and understand the experienced burden and distress. It would also be useful to psychometrically develop a tool to evaluate educational interventions. 


\section{Conclusions}

Sibling stem cell donors experience a learning process from before donation until at least one year afterwards involving motive, obligation, responsibility, preparation, circumstances, recovery and relationship. In the course of the year their perceptions of their experiences change and thereby their need for education, information and support. As the learning process stems from experiences of duty, pressure, burden, security, learning, struggle and closeness, there is a need to individualise the care and further study sibling stem cell donors' levels of burden and distress.

\section{ACKNOWLEDGEMENTS}

We would like to thank the sibling donors who took part in this study. We also thank Blodcancerfonden for the financial support that made this study possible.

\section{CONFLicts OF INTEREST Disclosure}

The authors declare they have no conflict of interest.

\section{REFERENCES}

[1] Passweg JR, Baldomero H, Bader P, et al. Use of haploidentical stem cell transplantation continues to increase: the 2015 European Society for Blood and Marrow Transplant activity survey report. Bone Marrow Transplantation. 2017; 52(6): 811-817. https : //doi.org/10.1038/bmt.2017.34

[2] Niederwieser D, Baldomero H, Szer J, et al. Hematopoietic stem cell transplantation activity worldwide in 2012 and a SWOT analysis of the Worldwide Network for Blood and Marrow Transplantation Group including the global survey. Bone Marrow Transplantation. 2016; 51(6): 778-785. https ://doi.org/10.1038/bmt.2016.1 8

[3] Sureda A, Bader P, Cesaro S, et al. Indications for allo- and auto-SCT for haematological diseases, solid tumours and immune disorders: current practice in Europe. Bone Marrow Transplantation. 2015; 50(8): 1037-1056. https://doi.org/10.1038/bmt.2015.6

[4] Halter J, Kodera Y, Ispizua AU, et al. Severe events in donors after allogeneic hematopoietic stem cell donation. Haematologica. 2009; 94(1): 94-101. https://doi.org/10.3324/haematol.13668

[5] Pulsipher MA, Chitphakdithai P, Logan BR, et al. Lower risk for serious adverse events and no increased risk for cancer after PBSC vs BM donation. Blood. 2014; 123(23): 3655-3663. https://doi .org/10.1182/blood-2013-12-542464

[6] Christopher KA. The experience of donating bone marrow to a relative. Oncology Nursing Forum. 2000; 27(4): 693-700. PMid: 10833697.

[7] Garcia MC, Chapman JR, Shaw PJ, et al. Motivations, experiences, and perspectives of bone marrow and peripheral blood stem cell donors: thematic synthesis of qualitative studies. Biology of Blood and Marrow Transplantation. 2013; 19(7): 1046-1058. https : //doi.org/10.1016/j.bbmt.2013.04.012

[8] Kisch A, Bolmsjö I, Lenhoff S, et al. Being a haematopoietic stem cell donor for a sick sibling: Adult donors' experiences prior to donation. European Journal of Oncology Nursing. 2015; 19(5): 529-535. https://doi.org/10.1016/j.ejon.2015.02.014

[9] Pillay B, Lee SJ, Katona L, et al. The psychosocial impact of haematopoietic SCT on sibling donors. Bone Marrow Transplantation. 2012; 47(10): 1361-1365. https://doi.org/10.1038/bm t. 2012.22

[10] Ekman I. (ed). Personcenteredness within health care. From philosophy to practice [in Swedish]. Liber: Stockholm; 2014

[11] Sjöström B, Dahlgren LO. Applying Phenomenography in nursing research. Journal of Advanced Nursing. 2002; 40(3): 339-45. https://doi.org/10.1046/j.1365-2648.2002.02375.x
[12] Marton F. Phenomenography. Describing conceptions of the world around us. Instructional Science. 1981; 10(2): 177-200. https: //doi.org/10.1007/BF00132516

[13] Patton MQ. Qualitative Research Evaluation Methods. 3rd edn. Sage: London; 2002.

[14] World Medical Association. World Medical Association Declaration of Helsinki: ethical principles for medical research involving human subjects. JAMA. 2013; 310(20): 2191-4. https ://doi .org/10.1 001/jama.2013.281053

[15] Tong A, Dew MA. Qualitative Research in Transplantation: Ensuring Relevance and Rigor. Transplantation. 2016; 100(4): 710-712. https://doi.org/10.1097/TP.0000000000001117

[16] Tong A, Morton RL, Webster AC. How Qualitative Research Informs Clinical and Policy Decision Making in Transplantation: A Review. Transplantation. 2016; 100(9): 1997-2005. https ://doi.org/10 $.1097 /$ TP .0000000000001358

[17] Brown JB, Karley ML, Boudville N, et al. Living kidney donors' experiences with the health care system. Social Work in Health Care. 2008; 46(3): 53-68. https ://doi.org/10.1300/J010v46n03_0 3

[18] Langenbach M, Stippel A, Stippel D. Kidney donors' quality of life and subjective evaluation at 2 years after donation. Transplantation Proceedings. 2009; 41(6): 2512-2514. https ://doi.org/10.101 $6 / j$.transproceed.2009.06.122

[19] Shaw R. Rethinking elements of informed consent for living kidney donation: findings from a New Zealand study. Health Sociology Review. 2015; 24(1): 109-122. https://doi.org/10.1080/144612 42.2015 .1016993

[20] Munzenberger N, Fortanier C, Macquart-Moulin G, et al. Psychosocial aspects of haematopoietic stem cell donation for allogeneic transplantation: how family donors cope with this experience. Psychooncology. 1999; 8(1): 55-63. https://doi.org/10.1002/(SICI) 1 099-1611(199901/02) 8:1<55: :AID-PON333>3 . 0.CO; 2-0

[21] van Walraven SM, Ball LM, Koopman HM, et al. Managing a dual role-experiences and coping strategies of parents donating haploidentical G-CSF mobilized peripheral blood stem cells to their children. Psycho-Oncology. 2012; 21(2): 168-175. https: //doi.org/10.1002/pon.1885

[22] Switzer GE, Dew MA, Magistro CA, et al. The effects of bereavement on adult sibling bone marrow donors' psychological well-being and reactions to donation. Bone Marrow Transplantation. 1998; 21(2): 181-188. PMid: 9489636. https://doi.org/10.1038/sj.bmt .1701063 